\title{
THE ROLE OF TECHNOLOGY IN BUILDING A RESILIENT CITY: MANAGING NATURAL DISASTERS
}

\author{
Mohammed Ali Berawi ${ }^{1 *}$ \\ ${ }^{1}$ Faculty of Engineering, Universitas Indonesia, Kampus UI Depok, Depok 16424, Indonesia
}

Catastrophic losses, as a result of natural disasters, have caused fatalities and destroyed urban areas. Therefore, there must be well-established approaches to planning an adaptation to climate change. Well-prepared urban plans, (re)development, operations, and maintenance after a natural disaster are necessary to build a resilient city.

In coming decades, this will be essential for urban developmental policy. Climate change will have a serious impact on cities if it is not properly managed. Climate forecasting and modeling should be employed to identify the impacted developmental sectors, in order to reduce vulnerability, as well as to develop a robust infrastructure that is able to withstand future stress. The development of urban ecosystems and green infrastructure are necessary assets to build a sustainable and supple city.

Rendering cities safe from disaster is a concern for all parties. Governments, the private sector, professionals, as well as citizens need to be engaged and contribute to building urban areas that can overcome natural disasters. Better policies and tools are required to anticipate these problems and to ensure urban development sustainability. Urban sustainability provides continual reasons to upgrade the public infrastructure, produce renewable energy, food, and water security, increase safety, and leads to urban renewal.

The development of a strong city requires continual commitment and support from the government and engagement of the public in response to disaster mitigation and prevention. Participatory budgeting, monitoring, and planning are required to enable the allocation of funding, after identifying vulnerable urban areas. Citizen empowerment is crucial in mitigating disaster impact, including the ability to adapt to shocks and stresses, and to quickly respond to a changing environment. The choice of land and environment to build new urban developments and the enforcement of effective building codes is required.

Although there are dedicated financial supports for such causes, the utilization of public-private partnerships can be employed to reduce further financial constraints. There are opportunities to involve the private sector. For instance, the government and private sectors could develop infrastructure in which the utilization of modern technology is employed, which results in savings of operational costs and better service.

\section{The Use of Technology in Mitigating Disaster}

The cities are required to update their public policies and urban development standards. By considering an urban area's economic, environmental, and social well-being, cities are expected to have better preparation for climate change. A contingency plan is required to anticipate unpredictable disasters, which involves an increase in capacity to manage natural disasters-particularly for shelter, food, water, and energy--the basic needs.

Understanding disaster in its various dimensions, such as the vulnerability it exposes and its impact, is necessary to implement effective policies and practices for disaster management, including

\footnotetext{
*Corresponding author's email: maberawi@eng.ui.ac.id, Tel. +62-21-7270029, Fax. +62-21-7270028

Permalink/DOI: https://doi.org/10.14716/ijtech.v9i5.2530
} 
appropriate preparedness and an effective response. The technology that is required encompasses disaster prediction, monitoring, mitigation, in addition to rescue operations and rehabilitation management.

Information and Communication Technologies (ICTs) contribute a significant role in disaster prevention, mitigation, and management. ICTs can be utilized as tools to dispatch early warning information, as well as to track and communicate during emergency situations and post-disaster periods. Timely, predictable, and effective information is required by government agencies and stakeholders that are involved in rescue operations and decision-making processes. The technological advancement that employs urban development datasets (e.g., infrastructure, environmental area locators, weather and seismic wave predictors, and real-time monitoring) has enabled the construction of models to predict damages and fatalities, as well as identification of areas that can flourish from city redevelopment.

For instance, Indonesia, and other countries, are prone to earthquakes, floods, and tsunamis, and therefore require resilient urban area and infrastructure development. The devastating 7.5 magnitude earthquake that was followed by a tsunami on Sulawesi Island in Indonesia last month demonstrates that quick responses from the government, disaster relief organizations, and the local and international community of Indonesia has enabled better stakeholder coordination with regards to mitigating the disaster impact. The use of different information and communication technologies, including satellite imagery through the Geographic Information Systems (GIS), radio and television, mobile networks, drones, the internet, and social media contributes to enhancing capacity and reducing vulnerability. Immediate information regarding damaged areas and the location of people who remain stranded, as well as emergency management to develop more targeted response plans, has been conducted with technological advancements.

Learning from catastrophes around the world, there should be a greater emphasis on the development of novel technologies for disaster mitigation and further construction of stronger cities. Disaster preparedness and management is the only effective method of mitigating the impact of future catastrophes.

\section{Advancing Technology Capacity}

In this edition, we are pleased to present twenty selected papers that are dedicated to advancing technology in terms of strengthening scientific research, technological capacity, and innovation.

The first paper, written by A. Elhamraoui, E. Abdelmounim, J. Zbitou, H. Bennis, M. Latrach, and A. Tajmouati, presents a novel, dual-band, microstrip antenna that is easily integrated into portable Radio Frequency Identification (RFID) readers. The authors argue that stable radiation pattern performances and a good matching input impedance at the desired operating frequencies is achieved.

The next paper, written by M. Suryanegara and M. Asvial, presents the pattern of innovation agendas for $5 \mathrm{G}$ mobile technologies. The authors argue that innovation agendas have "millimeter wave" and "energy" as the main technical issues, followed by technological platforms, productivity, and wireless infrastructure that shape the overall profile of $5 \mathrm{G}$ mobile development.

The third paper, written Y.A. Yatmo, N. Putra, M.M.Y. Harahap, and D.P. Saginatari, investigates the airborne transmission of diseases in relevance to spatial layout in healthcare facilities. The authors posit that there is a significant influence from airflow-related spatial objects, such as an internal fan, air conditioner, and their openings, on the droplet movement pattern.

The fourth paper, written by S. Hansen, E. Too, and T. Le, examines lessons that are learned from a cancelled urban transport project, as a result of a front-end planning (FEP) phase. The authors 
argue that it is crucial to develop an adequate FEP, and project viability and cancellation procedure to mitigate the loss of resources.

The fifth paper, written by L.Z. Mase, presents a reliability study of spectral acceleration designs against earthquakes. The author writes that the designed spectral acceleration is still able to cover the spectral acceleration that results from the wave propagation of the controlling earthquake, however, for $\mathrm{Tn}<0.2 \mathrm{~s}$ and $0.2 \mathrm{~s}<\mathrm{Tn}<0.7 \mathrm{~s}$, the designed spectral acceleration for three site classes (soft soil, medium soil, and stiff soil) are exceeded by the spectral acceleration.

The next paper, written by H. Yaacob, F.L Chang, R.P. Jaya, M.R. Hainin, A.S.A. Rashid, and N.A. Hassan, investigates the employment of a shear box device to measure the bond condition between the wearing and binder course layers in hot mix asphalt pavement. The authors contend that the interface shear strength increases, as the tack coat application rates and the wearing course layer thickness increases.

The seventh paper, written by N. Sharfan, A. Shobri, F.A. Anindria, R. Mauricio, M.A.B. Tafsili, and Slamet, investigates the treatment of batik industry waste with the combination process of electrocoagulation and photocatalysis. The authors communicate that the utilization of an aluminum plate as an anode, a stainless steel 316 plate as a cathode, and titanium oxide $\left(\mathrm{TiO}_{2}\right)$ coated on aluminum plates has been successful in the decolorization of Remazol Red dye, the elimination of 2,4,6-trichlorophenol, and the reduction of Chromium (Cr) (VI), simultaneously.

The eighth paper, written by E.K. Tetteh, K.O. Ansah-Amano, D. Asante-Sackey, and E. Armah, examines the effects of co-digestion operating conditions for the enhancement of biogas production from Miscanthus Fuscus mixed with cow dung. The authors note that a mixture of organic wastes for biogas production can reduce waste generation and produce more green energy.

The next paper, produced by A. Haris, A.D. Prasetio, A. Riyanto, and S. Mardiyati, investigates the P-impedance character of the thin reservoir in-basin, with geostatistical seismic inversion. The authors write that the model produces a higher resolution of P-impedance and enhances the optimization of seismic and petrophysical properties of the thin reservoir.

The tenth paper, presented by T. Hudaya, H. Kristianto, and C. Meliana, examines the simultaneous oxidation of cyanide and reduction of cadmium from electroplating wastewater through $\mathrm{UV} / \mathrm{TiO}_{2}$ photocatalysis. The authors argue that cadmium-cyanide wastewater treatment with $\mathrm{UV} / \mathrm{TiO}_{2}$ photocatalysisl, with an intensity of approximately $20 \mathrm{~W} / \mathrm{L}$, could remove more than $95 \%$ of pollutants, when optimized.

The eleventh paper, written by B. Priyono, A.H. Yuwono, B. Munir, M. H. Mustofa, and Faizah, presents nanostructure properties and the dye-sensitized solar cell (DSSC) open-circuit voltage of a $\mathrm{TiO}_{2}$ aerogel and pre-hydrothermally treated xerogels. The authors write that DSSCs that are fabricated by pre-hydrothermal treatment at $120^{\circ} \mathrm{C}$ generate a higher voltage $(320 \mathrm{mV})$ than aerogel cells $(21 \mathrm{mV})$.

The next paper, submitted by T.E. Saraswati, K. Nugroho, and M. Anwar, presents an anticorrosion coating from ball-milled wood charcoal and $\mathrm{TiO}_{2}$ with a flame spray method. The authors argue that the coated substrates demonstrate a greater corrosion resistance to both acid and water, with the wood charcoal- $\mathrm{TiO}_{2}$-coated substrates slowing the corrosion rate.

The thirteenth paper, written by S. Harjanto, J.F. Fatriansyah, L.N. Noviana, and S.W. Yunior, presents a mechanism of producing activated carbon from low-rank coal through a mechanochemical method, and determine its adsorption parameters. The authors communicate that the isosteric heat of adsorption increases rapidly at the initial and final stages of adsorption, because of the adsorption of hydrogen on smaller micropores, which reside inside larger ones. 
The fourteenth paper, presented by P. Palamba, M.L. Ramadhan, A.S. Pamitran, G. Prayogo, E.A. Kosasih, and Y.S. Nugroho, utilizes isothermal drying kinetics analysis to manage the peat fire process. The authors state that raising the temperature will increase the existing kinetic energy, and break the molecular bonds when collisions occur.

The next paper, written by M.T. Pham, A.T. Hoang, A.T. Le, A.R.M.S Al-Tawaha, V.H. Dong, and V.V. Le, presents the kinematic viscosity and density of biodiesel blends and fossil diesel fuel. The authors write that the proposed dual model, on the basis of temperatures and volume fractions, to estimate the density and kinematic viscosity of pure biodiesel and biodiesel-diesel fuel blends, is established.

The sixteenth paper, submitted by F.A. Nugroho, B. Siregar, G.L. Putra, and R. Dhelika, investigates the alteration of geometrical dimensions of tee stiffeners towards ultimate strength characteristics under a vertical bending load. The authors communicate that the ultimate strength, section modulus, and mass are influenced by the alteration of the web length and plate thickness.

The next paper, written by A. Purnowidodo , K. Anam, D.B. Darmadi, and A. Wahjudi, investigates the effect of fiber orientation and stress ratio on the crack growth behavior of fiber metal laminates (FMLs). The authors state that the crack growth behavior is affected by the stress ratio and the fiberglass orientation.

The eighteenth paper, presented by L. Gozali, M. Masrom, T.Y.M. Zagloel, H.N. Haron, D. Dahlan, F.J. Daywin, M.A. Saryatmo, D. Saraswati, A.F. Syamas, and E.H. Susanto, examines the effect of critical success and moderation of factors in the business incubators of public universities. The authors write that the utilization of a good system and infrastructure, information technology, mentoring, and networking are amongst the factors for success.

The nineteenth paper, written by I.B.M.P. Jandhana, T.Y.M. Zagloel, and R. Nurcahyo, examines the resilient structure assessment with the Cobb-Douglas production function in the metal industry. The authors communicate that currency shock, represented by an alteration in the exchange rate, impacts not only sector growth, but also the composition of labor expenses, capital investments, and the total factor productivity (TFP) in the sector.

The last paper, submitted by I. Masudin, F.W. Fernanda, and Widayat, assesses halal sector logistics performance and customer loyalty. The authors state that various factors affect the customer loyalty, such as halal supplier service quality, perceived service value, and customer satisfaction.

I hope that this edition of IJTech conveys new insights to the method with which we conduct our research. I am pleased to accept and respond to any comments or enquiries that you may have regarding the direction and content of IJTech, and I invite you to join us in this venture by sending your work for consideration.

With warmest regards from Jakarta,

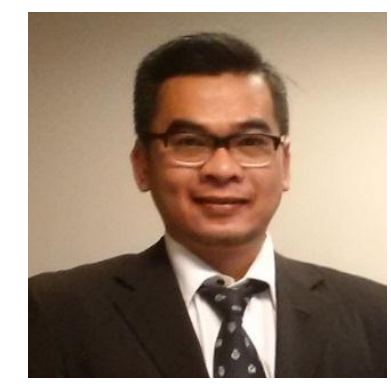

Dr. Mohammed Ali Berawi Editor in Chief 